\title{
Fractionation of Secondary Metabolites from Tulsi (Ocimum sanctum) and Aloe Vera (Aloe barbadensis Mill.) and their Antifungal Activity against Aspergillus niger and Sclerotium rolfsii
}

\author{
A. V. Chinche, R. M. Gade*, A. N. Shinde, M. T. Vairagade and K. V. Kendhale \\ Vasantrao Naik College of Agricultural Biotechnology, Yavatmal, India \\ *Corresponding author
}

\section{A B S T R A C T}

K e y w o r d s
Secondary
metabolites,
Ocimum sanctum,
Aloe barbadensis
Mill, Aspergillus
niger, Sclerotium
rolfsii,

\section{Keywords}

Secondary metabolites, Ocimum sanctum Aloe barbadensis rolfsii,

\section{Accepted:}

Available Online:

10 May 2020
An investigation was undertaken on fractionation of secondary metabolites from Ocimum sanctum and Aloe barbadensis Mill to check their antifungal activity against Aspergillus niger and Sclerotium rolfsii. Isolation of secondary metabolites was done by cold percolation and soxhlet extraction method with Methanol. Cold percolation method was found effective to get more phytochemicals. Analysis was done to check the presence of phytochemicals likes Alkaloids, Tannins, Saponins, Phenols, Flavonoids, Glycosides, Steroids and Terpenoids. Also qualitative tests viz. detection of Alkaloids was carried out by Wagner's reagent, Glycosides by Keller-killiani test, steroids by concentrated H2SO4, Tannins by $0.1 \mathrm{~N} \mathrm{HCl}$, Saponins by distilled water, Phenol by Ferric chloride, Flavonoids by concentrated H2SO4. Except phenol all components were present in both Ocimum sanctum and Aloe barbadensis Mill leaves extract. Presence of these components was determined by colour change or foam development after adding reagents into extract. Thin layer chromatography was done for the separation of different chemical constituents present in methanolic extracts. During standardization of eight different solvent systems Chloroform: Ethyl acetate : Acetic acid (50:50:1 $\mathrm{v} / \mathrm{v})$ found effective for the separation of Ocimum sanctum and Toluene : Ethyl acetate (93:7 v/v) for Aloe barbadensis Mill for the seperation of different components. scrapping of desired bands on TLC of partially purified compound used to check the antifungal activity against Aspergillus niger and Sclerotium rolfsii using poisoned food method. Different concentrations i.e. $20 \mathrm{mg}, 40 \mathrm{mg}$, and $60 \mathrm{mg}$ were taken, amongst $60 \mathrm{mg}$ showed significant growth inhibition as against $20 \mathrm{mg}$.

\section{Introduction}

Secondary metabolites like Tannins, Terpenoids, Alkaloids, Flavonoids play an important role in plant protection. Pharmaceuticals and pesticide industries are blessed with these economically important organic compounds (Patel and Jasrai, 2009; Wavare et al., 2017). There are many phytochemical available out of that nearly around ten thousand are plant secondary metabolites. These chemicals are having a defensive role and well established in the management of human diseases but their role in the management of plant diseases is still lacking (Satish et al., 2007 and Taiga et al., 2008). Phenols, Flavonoids, Quinones, Tannins, Alkaloids, Saponins, Sterols and 
Terpenoids available in higher plants having a rich diversity of bioactive secondary substances giving the advantage to explore alternative sources to chemicals and supplementary benefit of their eco-friendly nature (Tripathi and Dubey, 2004, Wavare et al., 2015; More et al., 2017).

Aloe vera is rich in Vitamins, Minerals, Enzymes, Sugars, Phenolic compounds, Lignin, Saponins, Sterol and Amino acids. The inner gel of the leaves has many biological properties with the major secondary metabolites like Anthraquinones and tricyclic aromatic quinines (Maharjan et al., 2015).

Similarly, the genus Ocimum is known as King of herbs and recognized for its therapeutic use having a lot of economic, nutritional, industrial and medicinal properties. Alkaloids are anti-oxidant and antimicrobial, Flavanoids and Phenolics are antimicrobial and antifungal, Tannins are anti-inflammatory and antioxidant (Simon et al., 1990). Aspergillus niger and Sclerotium rolfsii caused enormous losses in Agriculture crops.

Therefore, the present investigation is an attempt to explore the possibility of utilizing such huge biological material against plant pathogens. The results will open a new horizon in the field of Agriculture. The present study was, therefore, aimed at evaluating the phytochemical potential and antifungal activity of Ocimum sanctum and Aloe barbadensis Millmethanolic leaf extracts against plant pathogens.

\section{Materials and Methods}

Isolation and maintenance of fungal pathogen cultures were done by using Potato Dextrose Agar (PDA). The pure culture of these isolates was maintained on slants for further studies.

\section{Soxhlet extraction}

The leaf samples were dried at a temperature of about $40-45^{\circ} \mathrm{c} .40 \mathrm{~g}$ of fine powder of plant material was placed in a small size of muslin cloth bag in a soxhlet apparatus. The glycerin was kept at the joint of the extraction chamber and also at the mouth of the condenser to stop the leakage. The extraction chamber was filled with $250 \mathrm{ml}$ of Methanol as a solvent through the open end so that the powder was properly dipped in it. The extraction was carried out until the extract was colourless. The extracts were filtered through Whatman filter paper no.1. The filtrate was then evaporated at $40^{\circ} \mathrm{c}$ and stored at $4{ }^{\circ} \mathrm{c}$ for further analysis.

\section{Cold percolation}

The leaves samples were dried at the temperature of about $40-45^{\circ} \mathrm{c}$ for 3-4 days and made fine powder out of that $20 \mathrm{~g}$ powder was added into a conical flask containing 200 $\mathrm{ml}$ of Methanol as the solvent. This was kept at room temperature for about $72 \mathrm{hrs}$. The stirring of solution was done every 4-5 hrs. After that solution was filtered out by using Whatman filter paper. Finally, filtrate was transferred into an oven at the temperature of about $60-62^{\circ} \mathrm{c}$ which is the melting point of Methanol to evaporate the solvent and got solid extract. The extract was kept in a refrigerator at $4^{\circ} \mathrm{c}$ to be used for further studies. Noted down the weight of each Petri dish prior to drying of the extracts and after drying too. The calculated weight of the extracts from that difference. The yield of the extract was calculated in grams and converted into a percentage.

\section{Thin layer chromatography}

Thin layer chromatography was carried out to know the chemical profile of methanolic extract of Ocimum sanctum L. and Aloe 
barbadensis Mill. TLC plates were prepared with $25 \mathrm{~g}$ of silica gel-G (Hi media, Manufactured India) mixed with $50 \mathrm{ml}$ of distilled water and the slurry formed was uniformly spread with the use of spreader on TLC plates of $0.25 \mathrm{~mm}$. The plates were allowed to dry at room temperature and heated in an oven at $100^{\circ} \mathrm{c}$ for $2 \mathrm{hrs}$.

\section{Standardization of solvent system}

Sample of the crude extract Ocimum sanctum L. and Aloe barbadensis Mill. Leaves extract were diluted in the respective solvent. The prepared TLC plates were marked $1 \mathrm{~cm}$ from bottom and $10 \mathrm{ul}$ each sample was applied on TLC plates at equal distance with the help of capillary tubes. For separation of maximum bands on TLC plates, different solvent systems were used according to polarity and from that Chloroform: Ethyl acetate : Acetic acid (50:50:1) and Toluene : Ethyl acetate (93:7), for Ocimum sanctum L. and Aloe barbadensis Mill. respectively extract was selected as standard solvent system.

TLC plates were kept in chromatography chambers, containing Chloroform: Ethyl acetate : Acetic acid (50:50:1), Toluene : Ethyl acetate (93:7) as a solvent system for respective leaves extract and allowed to run so that it can reach to 3/4th position. The developed chromatogram on TLC plates was allowed to air dry and observed under visible UV light. The colour of the bands was noted and the $\mathrm{Rf}$ value (Relative front) of separated bands was calculated by measuring the distance traveled by solute and the solvent.

\section{Preliminary phytochemical screening of leaves extracts}

Preliminary phytochemical analysis of methanolic extracts from Ocimum sanctum $L$. and Aloe barbadensis Mill were performed for analysis of different phytochemical like
Cardio glycosides, Saponins, Alkaloids, Steroids, Terpenoids, Flavonoids, Tannins and Phenolic compounds by following the methods given by Trease and Evans (1978).

\section{Test for detection of alkaloid}

$1 \mathrm{ml}$ of extract was taken in a test tube, followed by the addition of $1 \mathrm{ml}$ of Wagner's reagent. The appearance of brown flocculent and precipitation reveals the presence of Alkaloids.

\section{Test for detection of tannins}

$1 \mathrm{ml}$ of the extract was taken in a test tube, and then $1 \mathrm{ml}$ of $0.1 \%$ Ferric chloride-containing $0.1 \mathrm{~N}$ HCL was added. The appearance of blue-black coloration indicates the presence of Tannins.

\section{Test for detection of saponins}

The extract was mixed with $5 \mathrm{ml}$ distilled water and then agitated in a graduated cylinder for $15 \mathrm{~min}$. The presence of Saponins confirmed with the presence of foam.

\section{Test for phenols}

Ferric chlorides were added to $1 \mathrm{ml}$ of extract in a test tube. The development of a dark green color indicates the presence of phenols.

\section{Test for flavonoids}

In $1 \mathrm{ml}$ of extract, $1 \mathrm{ml}$ of dilute ammonia solution was added followed by the addition of concentrated $\mathrm{H} 2 \mathrm{SO} 4$ dropwise. A yellow coloration observed indicates the presence of Flavonoids.

\section{Test for glycosides (keller-kiliani test)}

About $1 \mathrm{ml}$ of the extract was treated with 1 $\mathrm{ml}$ of Glacial acetic acid containing one drop 
of Ferric chloride solution. This was underlaid with $1 \mathrm{ml}$ of concentrated $\mathrm{H} 2 \mathrm{SO} 4$. A brown ring at the interface indicates the presence of Glycosides.

\section{Test for steroids}

About $2 \mathrm{ml}$ of Acetic anhydride was added to $1 \mathrm{ml}$ crude extract of plant sample with $2 \mathrm{ml}$ $\mathrm{H} 2 \mathrm{SO} 4$. The presence of Steroids confirmed when colour change from violet to blue or green.

In vitro evaluation of plant extracts by poisoned food technique on PDA medium

The efficacy of Methanol extracts of Ocimum sanctum L. and Aloe barbadensis Mill whole plant extracts at 20, 40, and $60 \mathrm{mg} /$ lit were tested against Sclerotium rolfsii in vitro under condition following poisoned food technique on PDA medium. The suspension of 20, 40, and $60 \mathrm{mg} / \mathrm{lit}$ of methanolic crude extracts were poured separately in Petri plates containing $20 \mathrm{ml}$ sterilized PDA medium.

The plates were rotated for some time for uniform mixing of the crude extract with medium and then allowed for solidification. Three replications for each treatment were used. All the plates were inoculated individually with $5 \mathrm{~mm}$ diameter discs of the test fungal cultures and then incubated at $28 \pm 2{ }^{\circ} \mathrm{C}$ until the control plates reached full growth. The percent of growth inhibition of test fungus was calculated by using a formula suggested by Vincent (1947).

\section{Results and Discussion}

\section{Extraction yield}

Extraction is the major step for obtaining phytochemicals from plants. Standardization of extraction and accurate use of solvent information about the interfering substances are important in the process (Stalikas et al., 2007). In this experiment Ocimum sanctum $L$. and Aloe barbadensis Millextracts were obtained by using Methanol. The Methanol was the best solvent to give sufficient extraction yield and was the most capable to extract more substances that preferably dissolved in Methanol. Maximum extraction yield of Ocimum sanctum L. (15.99\%) and Aloe barbadensis Mill. (16.38\%) was obtained in Methanol (Ncube and Okoh, 2008., Gurjar et al., 2012; Wavare et al., 2016).

This indicates that the extraction yield of pure Methanol (15.99\% and 16.38\%) increases due to polarity of the solvent used in extraction. The solubility of proteins and carbohydrates in Methanol may be attributed to get more extraction yield (Zieliński, 2000). The results of this study are also in agreement with the extraction yields obtained from medicinal plants (Sultana, 2009).

\section{Thin layer chromatography (TLC)}

Each sample of the crude extracts of Ocimum sanctum L. and Aloe barbadensis Mill. was diluted in distilled water. The prepared TLC plates were marked $1 \mathrm{~cm}$ from the bottom and $10 \mu l$ each sample was applied on TLC plates at equal distance with the help of capillary tubes. For the separation of maximum bands on TLC plates, different solvent system were used according to polarity and from that Chloroform : Ethyl acetate : Acetic acid $(50: 50: 1 \mathrm{v} / \mathrm{v})$ and Toluene : Ethyl acetate $(93: 7 \mathrm{v} / \mathrm{v})$ was selected as a standard solvent systems for Ocimum sanctum L. and Aloe barbadensis Mill. Thin layer chromatography was carried out for the efficient separation of different chemical constituents present in Methanol extracts and Rf values and colour of separated bands in different solvent systems under UV- transilluminator were noted. 


\section{Standardization of solvent system}

Various solvent systems were screened for efficient separation of bands according to polarity. Total of 8 solvent systems were used in the present investigation to know most suitable solvent system for the separation of compounds in the methanolic extract of Ocimum sanctum $L$. and Aloe barbadensis Mill. The Rf values and colour of the separated bands in different solvent systems under UV-transilluminator are summarized in Table 1 and Table 2. There were significant differences according to solvent system in the number of bands and their $\mathrm{Rf}$ values in methanolic extracts. Among all the tested solvent systems, the Rf values of the best solvent system for the methanolic extract of Ocimum sanctum $L$. run under Chloroform : Ethyl acetate : Acetic acid (50:50:1 v/v) was found $0.78,0.66$, and 0.12 with separated and clear bands. These observations are in accordance with the findings of Shitole et al., 2017 who carried out methonolic extraction of $P$. corylifolia seed using Toluene : Ethyl acetate : Methanol (20:04:02 v/v) solvent system. It is seen that Methanol not only best for extraction of polar compounds but some of the non-polar compounds soluble at certain extent in methanol: chloroform in solvent system may boost the extraction yield if compound is strictly hydrophobic. Low boiling point may be the reason to get extraction and concentration of bioactive compounds in soxhlet extraction.For Aloe barbadensis Mill. Different solvent systems (Table 2) were standardized. Among all other solvent systems, found best for methanolic extracts of Aloe barbadensis Millwas Toluene: Ethyl acetate $(93: 7 \mathrm{v} / \mathrm{v})$. The RF values obtained for these solvent systems were $0.69,0.25,0.03$ (Table 2). More et al., 2016 observed the most promising solvent system for methanolic extracts of $A$. marmelose run under petroleum ether: ethyl acetate (02:01). The results are also in confirmation with the findings of Masuduzzaman et al., (2008) who observed separated compounds of all amanda leaf aqueous extract on TLC plate eluted with Hexane: Benzeen (1:1) and Benzene: Ethyl acetate, respectively. Polar solvent system used in the experiment may be the reason for the separation of maximum number of compounds from methanolic extracts.

Table.1 Standardization of solvent system for methanol extract of Ocimum sanctum L.

\begin{tabular}{|c|c|c|c|c|}
\hline \multirow[t]{2}{*}{$\begin{array}{l}\text { Sr. } \\
\text { No }\end{array}$} & \multirow[t]{2}{*}{ Solvent System } & \multirow[t]{2}{*}{ Proportion } & \multicolumn{2}{|c|}{$\begin{array}{l}\text { Methanolic Extract Of } \\
\text { Ocimum sanctum } L \text {. }\end{array}$} \\
\hline & & & $\mathbf{R f}$ & Colour \\
\hline $\mathbf{1}$ & Toluene : Ethyl acetate : Formic acid & 7:2.7:0.3 & 0.97 & Green \\
\hline 2 & Chloroform : Hexane : Acetic acid & $50: 50: 1$ & 0.91 & Green \\
\hline 3 & Ethyl acetate : Acetone & $4: 6$ & $\begin{array}{l}0.89 \\
0.68\end{array}$ & $\begin{array}{l}\text { Pink } \\
\text { Dark Blue }\end{array}$ \\
\hline 4 & Toluene : Ethyl acetate : Methanol & $24: 5: 2$ & 0.88 & Dark Pink \\
\hline 5 & $\begin{array}{l}\text { Chloroform : Glacial acetic acid : Methanol : } \\
\text { Water }\end{array}$ & $16: 8: 3: 2$ & 0.87 & $\begin{array}{l}\text { Light } \\
\text { Yellow }\end{array}$ \\
\hline 6 & Ethyl acetate : Acetic acid : Petroleum ether & $20: 6: 4$ & 0.82 & $\begin{array}{l}\text { Green } \\
\text { Yellow }\end{array}$ \\
\hline 7 & Chloroform : Ethyl acetate : Acetic acid & $50: 50: 1$ & $\begin{array}{l}0.78 \\
0.66 \\
0.12\end{array}$ & $\begin{array}{l}\text { Green } \\
\text { Yellow } \\
\text { Pink }\end{array}$ \\
\hline
\end{tabular}


8 Toluene : Ethyl acetate

93:7

0.79

Light Pink

Table.2 Standardization of solvent system for methanolic extract of Aloe barbadensis Mill

\begin{tabular}{|c|c|c|c|c|}
\hline \multirow[t]{2}{*}{ Sr. No } & \multirow[t]{2}{*}{ Solvent System } & \multirow[t]{2}{*}{ Proportion } & \multicolumn{2}{|c|}{$\begin{array}{c}\text { Methanolic Extract } \\
\text { Of Aloe barbadensis } \\
\text { Mill. }\end{array}$} \\
\hline & & & $\mathbf{R f}$ & Colour \\
\hline 1 & Ethyl acetate : Toluene : Formic acid & $22: 11: 1$ & 0.79 & Yellow \\
\hline 2 & $\begin{array}{l}\text { Chloroform : Glacial acetic acid : } \\
\text { Methanol : Water }\end{array}$ & $16: 8: 3: 2$ & $\begin{array}{l}0.87 \\
0.70\end{array}$ & $\begin{array}{c}\text { Red } \\
\text { Yellow }\end{array}$ \\
\hline 3 & Chloroform : Hexane : Acetic acid & $50: 50: 1$ & 0.78 & Yellow \\
\hline 4 & Toluene : Ethyl acetate & $9: 2$ & $\begin{array}{l}0.86 \\
0.47\end{array}$ & $\begin{array}{l}\text { Pink } \\
\text { Blue }\end{array}$ \\
\hline 5 & $\begin{array}{l}\text { Ethyl acetate : Acetic acid : Petroleum } \\
\text { ether }\end{array}$ & $19: 1: 5$ & $\begin{array}{l}0.76 \\
0.59\end{array}$ & $\begin{array}{l}\text { Yellow } \\
\text { Blue }\end{array}$ \\
\hline 6 & Ethyl acetate : Acetone & $4: 6$ & 0.84 & Green \\
\hline 7 & Toluene : Ethyl acetate & $93: 7$ & $\begin{array}{l}0.69 \\
0.25 \\
0.03\end{array}$ & $\begin{array}{l}\text { Pink } \\
\text { Yellow } \\
\text { Green }\end{array}$ \\
\hline 8 & Petroleum ether : Toluene : Ethyl acetate & $3: 1: 1$ & 0.85 & Blue \\
\hline
\end{tabular}

Table.3 Preliminary phytochemical analysis of methanolic extract of Ocimum sanctum L. and Aloe barbadensis Mill

\begin{tabular}{|c|c|c|}
\hline Test & Ocimum sanctum L. & Aloe barbadensis Mill. \\
\hline Alkaloids & + & + \\
\hline Tannins & + & + \\
\hline Saponins & + & + \\
\hline Phenols & + & + \\
\hline Flavonoids & + & + \\
\hline Glycosides & + & + \\
\hline Steroid/ Terpenoids & + (Terpenoids) & $+($ Steroids $)$ \\
\hline
\end{tabular}

Table.4 Growth inhibition of Ocimum sanctum L. and Aloe barbadensis Mill

\begin{tabular}{|c|c|c|c|c|c|}
\hline \multicolumn{7}{|c|}{ Growth inhibition (\%) } \\
\hline $\begin{array}{c}\text { Concentration } \\
(\mathbf{m g} / \mathbf{m l})\end{array}$ & $\begin{array}{c}\text { Control } \\
(\mathbf{m m})\end{array}$ & \multicolumn{2}{l|}{ Ocimum sanctum $\mathbf{L}$} & \multicolumn{2}{c|}{ Aloe barbadensis Mill. } \\
\hline & & $\begin{array}{c}\text { Cold } \\
\text { percolation }\end{array}$ & $\begin{array}{c}\text { Soxhlet } \\
\text { extraction }\end{array}$ & $\begin{array}{c}\text { Cold } \\
\text { percolation }\end{array}$ & $\begin{array}{c}\text { Soxhlet } \\
\text { extraction }\end{array}$ \\
\hline $\mathbf{2 0} \mathbf{~ m g}$ & 00 & 21.55 & 10.55 & 10.40 & 10.2 \\
\hline $\mathbf{4 0} \mathbf{~ m g}$ & 00 & 33.33 & 32.44 & 22.22 & 21.22 \\
\hline
\end{tabular}




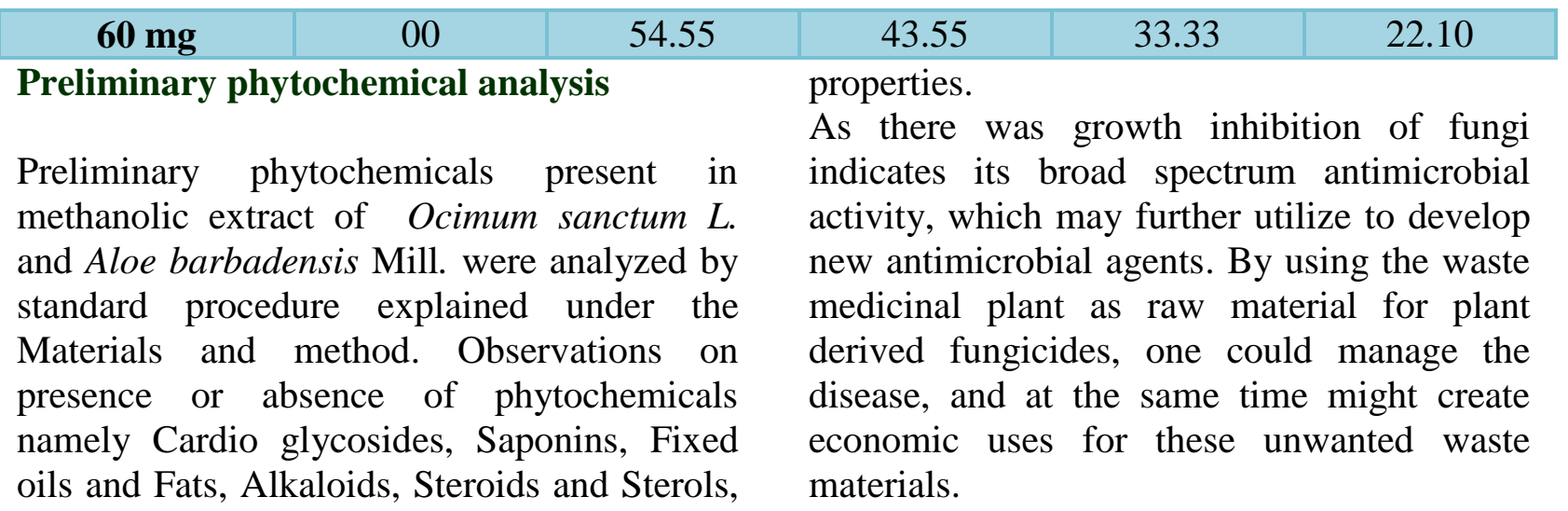
Flavonoids, Tannins and Phenolic compounds were noted as + for presence and - sign for absence and are presented in Table 3. The methanolic extract of Aloe barbadensis Mill. subjected to preliminary phytochemical screening by using standard procedures of Trease and Evans (1978). The results corroborate with the findings of Reddy et al., (2004) who analysed phytochemical and showed antimicrobial activity of Ocimum santum $L$.

\section{Efficacy of plant extracts on growth inhibition of Sclerotium rolfsii. by posion food method}

Data presented in Table 4. represents that, at highest concentration $(60 \mathrm{mg} / \mathrm{ml})$ maximum inhibition of mycelial growth of test fungus was recorded. Lowest growth inhibition of test fungus was recorded at the $20 \mathrm{mg} / \mathrm{ml}$ concentration of the methanolic extracts of Ocimum sanctum L. and Aloe barbadensis Mill. Similar results were observed by shitole et al., 2017 who screened the antimicrobial activity of methanolic extracts of $P$. corylifolia seeds against $S$. rolfsii where they found that $500 \mathrm{ul}$ (57.48 to $98.23 \%$ ) inhibits the mycelia growth. This broad spectrum antifungal activity of plant species was observed to be related to the presence of saponins, tannins and alkaloids. Although active components have not been identified but phenols, sterols, flavonoids, tannins and terpenoids supposed to have these anti-fungal

\section{Acknowledgements}

We are thankful to Associate Dean, VNCAB Yavatmal and University authorities for providing necessary facilities to carry out this research work

\section{References}

Gurjar, M.S., Ali, S., Akhtar, $\mathrm{M}$ and Singh, K.S. 2012. Efficacy of plant extracts in plant disease management.Agril. Sci. 3(3): 425433.

Maharjan, H., Radha and Nampoothiri, P. 2015. Evaluation of biological properties and clinical effectiveness of Aloe vera: A systematic review. J Tradit Complement Altern Med.5(1): 21-26.

More, Y., Gade, R.M., Wavare, S.H and Shitole, A.V. 2016. Phytochemical Investigation and Thin Layer Chromatography of Aegle marmelos Leaves Methanolic Extract. Advances in Life Sciences. 5(15): 5685-569.

More, Y.D., Gade, R.M and Shitole, A.V. 2017 Evaluation of antifungal activities of extracts of Aegle marmelos, Syzygium cumini and Pongamia pinnata against Pythium debaryanum. Indian J Pharm Sci. 79(3): 377384.

Masuduzzaman, S., Meah, M.B and Rashid, M.M. 2008. Determination of inhibitory action of Allamanda leaf extracts against some important plant pathogens.J. Agric. Rural Dev. 6(1 and 2): 107-112.

Ncube, N and Okoh, A.I. 2008. Assessment techniques of antimicrobial properties of natural compounds of plant origin: Current 
methods and future trends.Afr. J. of Biotechnol. 7: 1797-1806.

Nene, Y.L., Haware, M.P and Reddy, M.V. 1981. Chickpea disease resistance screening techniques. Information bulleting No. 10. International Crop Research Institute for Semi-Arid Tropics, Patancheru. 502324, A.P., India: pp. 1-3.

Patel, R and Jasrai, Y. 2009. Plant secondary metabolites and their commercial production. South Asian J. of Socio-Political Studies. 9(2): 116-122.

Rajput, V.A., Konde, S.A and Thakur, M.R. 2010. Evaluation of bioagents against chickpea wilt complex.J. Soils and Crops. 20(1): 155-158.

Reddy, N.M. 2004. Lantana camara Linn. chemical constituents and medicinal properties: A Review.Sch. Acad. J. Pharm. 2(6): 445-448.

Satish, S., Mohana, D.C., Ranhavendra, M.P and Raveesha, K.A. 2007. Antifungal activity of some plant extracts against important seed borne pathogens of Aspergillus sp. J. ofAgricul. Technol. 3(1): 109-119.

Shitole, A.V., Gade R.M and Wavare S.H. 2017. Bioefficacy of psoralea corylifolia $L$. against incitant of sclerotium rolfsii, collar rot of chickpea. J.Pl.Dis.Sci. 12(1): 029 - 036.

Simon, J.E., Quinn, J and Murray, R.G. 1990. Basil A source of essential oils, in new crops, Timber press Portland., 484-489.

Stalikas, C.D. 2007. Extraction, separation, and detection methods for phenolic acids and flavonoids.J Sep Sci. 30 (2007), pp. 32683295.

Sultana, B., Anwar, F and Ashraf, M. 2009. Effect of extraction solvent/technique on the antioxidant activity of selected medicinal plant extracts Molecules, 14 , 2167-2180.

Taiga, A., Suleiman, M.N., Sule, and Olufolaji, D.B. 2008. Comparative in vitro inhibitory effects of cold extracts of some fungicidal plants on Fusariumoxysporum mycelium. Afr. J. Biotech. 7(18): 3306-3308.

Trease, G.S and Evans, H.C. 1978. Phytochemical constituents of medicinal plants. Textbook of Pharmacognosy, $9^{\text {th }}$ edition. Bailiar Zindall Publishers., 18-25.

Tripathi, P and Dubey, N.K. 2004. Exploitation of natural products as an alternative strategy to control post-harvest fungal rotting of fruits and vegetables. Postharvest Biol. and Technol. 32: 235-245.

Vincent, J.H. 1947. Distortion of fungal hyphae in the presence of certain inhibitors. Nature, 15: 850.

Wavare, S.H., Gade, R.M., Belkar, Y.K., Vyavhare, G.F and Gawande, A.D. 2015. Compatibility of Marigold Water Extract with Biocontrol Agents. Trends in Biosciences 8(15): 4001-4006.

Wavare, S.H., Gade, R.M., Shitole, A.V and Ingole, M.N. 2016. Evaluation of floral extracts, biocontrol agents and fungicides for management of damping off of tomato caused Pythium debaryanum. The Ecoscan, Special issue, 9: 789-795.

Wavare, S.H., Gade, R.M and Shitole, A.V. 2017. Antifungal efficacy of floral extract, biocontrol agents and fungicides against $F$. oxysporum $f . \quad s p$. ciceri. Indian Phytopath.70(2): 191-1999.

Wavare, S.H., Gade, R.M and Shitole, A.V. 2017. Effect of plant extracts, bio-agents and fungicides against Sclerotium rolfsii causing collar rot in chickpea. Indian J Pharm Sci 79(4): 513-520.

Zieliński, H.H and Kozłowska. 2000. Antioxidant activity and total phenolics in selected cereal grains and their different morphological fractions. J Agric Food Chem, 48, pp.2008.

\section{How to cite this article:}

Chinche. A. V., R. M. Gade, A. N. Shinde, M. T. Vairagade and Kendhale. K. V. 2020. Fractionation of Secondary Metabolites from Tulsi (Ocimum sanctum) and Aloe Vera (Aloe barbadensis Mill.) and their Antifungal Activity against Aspergillus niger and Sclerotium rolfsii. Int.J.Curr.Microbiol.App.Sci. 9(05): 445-452.

doi: https://doi.org/10.20546/ijcmas.2020.905.050 